Психолого-педагогічні проблеми становлення сучасного фахівця Випуск 2018

УДК 37.013.77:502.22::37.091.212+57.081.1

DOI 10.26697/9786177089017.2018.319

Гончарук Віталій Володимирович

Черкаський національний університет імені Богдана Хмельницького

\title{
ПСИХОЛОГО-ПЕДАГОГІЧНІ УМОВИ ФОРМУВАННЯ ЕКОЛОГІЧНОЇ КУЛЬТУРИ МАЙБУТНІХ УЧИТЕЛІВ ПРИРОДНИЧИХ СПЕЦАЛЬНОСТЕЙ
}

У наш час актуальною є проблема оптимізації взаємодії людини $i$ природи за рахунок підвищення рівня екологічної культури молоді. Проаналізовано погляди вчених на специфіку формування екологічної культури студентів. Охарактеризовано п'ять взаємопов'язаних компонентів готовності студентів до формування екологічної культури учнів. Встановлено, що учитель природничих спеціальностей виконує вирішальну роль у здійсненні екологічного виховання дітей $i$ молоді.

Ключові слова: екологічна культура фахівців, екологічні знання, психолого-педагогічні умови формування екологічної культури учителів, навколишнс середовище.

Проблема, ïi зв'язок із важливими науковими чи практичними завданнями. Підготовка сучасних фахівців до екологічно виправданої діяльності у професійній сфері, формування у них екологічної культури є одним із пріоритетів професійної освіти та одним із шляхів реалізації положень Національної доктрини розвитку освіти України у XXI столітті, Закону України «Про освіту», Концепції екологічної освіти України та Концепції сталого розвитку України. Професійна діяльність учителя природничих спеціальностей спрямована на безперервність і гуманізацію навчання, на формування екологічної культури, на розвиток творчих здібностей і на розширення світогляду учнів. Значущість проблеми формування екологічної культури пов'язується, перш за все, з пошуками ефективних шляхів подолання екологічної кризи, яка набула глобального рівня і загрожує існуванню вищих форм життя, включаючи людину.

Аналіз публікацій (виділення невирішених проблем). Значна увага у педагогічній науці нині надається формуванню екологічної культури особистості, починаючи з раннього дитячого віку. Зокрема, методологічні підходи на засадах філософії та концептуальні положення екологічної освіти й виховання відображені у працях Г. Білявського, В. Бровдія, М. Дробнохода, О. Захлєбного, І. Звєрєва, М. Кисельова, Г. Пустовіта та інших. 
Різні аспекти формування екологічної культури майбутніх учителів, зокрема відповідальне ставлення до природного середовища, вивчення екологічних та еколого-педагогічних проблем розглядали такі науковці, як: О. Базалук, М. Бербець, О. Вернік, Е. Гірусов, О. Головко, С. Дерябо, В. Єрмолаєва, М. Кисельов, І. Костицька, С. Кравченко, В. Крисаченко, Т. Лиханова, Л. Лук'янова, М. Моісеєв, В. Некос, А. Толстоухов, С. Шмалєй.

Аналіз досліджень, які присвячені проблемі формування екологічної культури студентів, показав, що поки не сформовані необхідні засади розвитку цієї важливої проблеми, не визначений комплекс психолого-педагогічних умов, що сприяли б ефективному формуванню екологічної культури.

Ціль статті - розкрити психолого-педагогічні умови формування екологічної культури студентів природничих спеціальностей у закладах вищої освіти.

Формування екологічної культури майбутніх учителів природничих спеціальностей $є$ одним із найбільш відповідальних завдань сучасних педагогіки, соціально-філософської теорії і практики, яке тісно пов'язано з реакцією на глобальну екологічну кризу.

Виклад основного матеріалу, обгрунтування результатів дослідження. Екологічна культура, як і вся культура в цілому, діалектично взаємопов'язана 3 суспільними процесами, які відбуваються та обумовлена законами їх розвитку. Як соціальне явище, екологічна культура вчителя знаходиться у прямій залежності від тих суспільних відносин, у які вступає індивід. На основі теоретичного аналізу психолого-педагогічної літератури, вивчення передового педагогічного досвіду ми визначаємо екологічну культуру студента як інтегративну якість особистості, яка відповідає рівню розвитку її в сфері екологічної діяльності.

Стан екологічної освіти й виховання учнів значною мірою залежить від рівня сформованості екологічної культури вчителя i професійної готовності його до означеного напряму педагогічної діяльності. С. Совгіра слушно зазначила, що формування екологічної культури майбутнього викладача природничих дисциплін повинне проходити через: набуття екологічних знань, формування екологічного мислення, світогляду, етичних принципів поведінки у природі; проведення краєзнавчих екскурсій, експедицій, подорожей, вироблення активної природоохоронної позиції, формування необхідних якостей вихователя, організатора [2].

У дослідженні $€$. Флешар екологічна освіта розглядається як процес, у результаті якого формуються відповідні знання та навички теоретичної і практичної роботи у галузі охорони навколишнього середовища [4]. 
Л. Нікітченко було визначено такі педагогічні умови успішного формування названої вище компетентності: забезпечення поєднання теоретичного матеріалу із практичною діяльністю; активізація самостійної пізнавально-дослідницької діяльності студентів; надання цілям професійної підготовки у процесі навчання особистісного смислу [1].

На думку Л. Фенчак, основними педагогічними умовами формування екологічної культури $\epsilon$ : реалізація неперервності екологічної освіти у процесі підготовки фахівців шляхом урахування специфіки та вимог освітньо-кваліфікаційної характеристики спеціальності; відображення у змісті еколого-освітньої роботи регіональних екологічних проблем; екологізація виховної роботи на основі врахування народних звичаїв; реалізація діяльнісного підходу до формування екологічних знань, переконань, норм поведінки тощо [3].

Висновки, перспективи. Отже, ми зробили висновок, що успішний розвиток екологічної культури студентів природничих спеціальностей зумовлюється реалізацією у закладі вищої освіти таких педагогічних умов: формування у молодих людей умінь аналізувати явища природи та бережливо ставитися до неї як до середовища свого існування; використання інтерактивних методів навчання, зокрема, методики круглого столу, яка в активній формі дозволяе засвоїти базові теоретичні основи екології та вплинути на екоцентричну особистість студента за відносно короткий час; накопичення студентами необхідної інформації через відвідування інтернет сайтів; спілкування 3 досвідченими спеціалістами; поєднання аудиторної i позааудиторної природоохоронної роботи.

\section{Література}

1. Nikitchenko L. O. Forming Professional Competence in The Process of Teaching Biology Students / L. O. Nikitchenko // Наука і освіта. - 2017. - № 8. - C. 78-82.

2. Совгіра С. В. Підготовка майбутнього вчителя до екологічного виховання старшокласників (на краєзнавчому матеріалі) : дис. ... канд. пед. наук : 13.00.04 / С. В. Совгіра. - Умань, 1999. - 228 с.

3. Фенчак Л. М. Формування екологічної культури студентів вищих аграрних навчальних закладів I-II рівнів акредитації : автореф. дис. ... канд. пед. наук : спец. 13.00.04 / Л. М. Фенчак. - Тернопіль, 2006. -19 c.

4. Флешар Є. Дидактичні основи підготовки студентівмайбутніх учителів-біологів до реалізації екологічної освіти : автореф. дис. ... д-ра пед. наук / Є. Флешар. - К., 2000. - 30 с. 
Збірник наукових статей

Виталий Гончарук. Психолого-педагогические условия формирования экологической культуры будущих учителей естественных специальностей.

В наше время актуальна проблема оптимизации взаимодействия человека и природы за счет повышения уровня экологической культуры молодежи. Проанализированы взгляды ученых на специфику формирования экологической культуры студентов. Охарактеризованы пять взаимосвязанных компонентов готовности студентов $\kappa$ формированию экологической культуры учашихся. Установлено, что учитель естественных специиальностей выполняет решающую роль в осуществлении экологического воспитания детей $и$ молодежи.

Ключевые слова: экологическая культура спечиалистов, экологические знания, психолого-педагогические условия формирования экологической культуры учителей, окружающая среда.

Vitalii Honcharuk. Psychological and pedagogical conditions for the formation of ecological culture of future teachers of natural specialties.

The urgency of the problem of optimization man and nature interaction is revealed due to the level's increasing of future natural sciences teachers' ecological culture. The problem of ecological culture formation in future natural sciences teachers in the process of their professional training is considered. Five interconnected components of student readiness for the formation of students ecological culture are characterized. It is established that the teacher of natural specialties performs a decisive role in the implementation of ecological education of children and youth.

Keywords: ecological culture of specialist, ecological knowledge, psychological and pedagogical conditions for the formation of ecological culture of teachers, environment.

Стаття надійшла до редакційної колегії 17.05.2018

Прийнято до друку 18.05.2018

Інформація про автора:

Гончарук Віталій Володимирович - здобувач, Черкаський національний університет імені Богдана Хмельницького. 